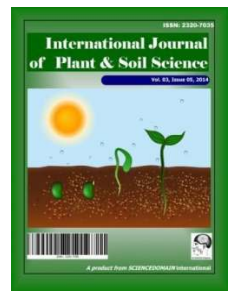

\title{
Responses of Bambara groundnut [Vigna subterranea (L.) Verdc.] to Phosphate Fertilizer Rates and Plant Spacing and Effects on Soil Nutrient Statues in a Degraded Tropical Ultisol Agbani Enugu South East Nigeria
}

\author{
E. E. Ikenganyia ${ }^{{ }^{\star}}$, M. A. N. Anikwe ${ }^{1}$ and O. E. Ngwu ${ }^{1}$ \\ ${ }^{1}$ Department of Agronomy and Ecological Management, Faculty of Agriculture and Natural Resources \\ Management, Enugu State University of Science and Technology, Agbani, Enugu State, Nigeria.
}

Authors' contributions

This work was carried out in collaboration between all the authors. All authors read and approved the final manuscript.

Article Information

DOI: $10.9734 /$ IJPSS/2017/32606

Editor(s):

(1) Francisco Cruz-Sosa, Biotechnology Department, Metropolitan Autonomous University Iztapalapa Campus, Av. San Rafael Atlixco 186 México City 09340, México.

Reviewers:

(1) Anélia Marais, Stellenbosch, South Africa. (2) Abdulmajeed Bashir Mlitan, Misurata University, Libya. (3) Mohd Hafiz Ibrahim, Universiti Putra Malaysia, Malaysia. Complete Peer review History: http://www.sciencedomain.org/review-history/20129

Original Research Article

Received $4^{\text {th }}$ March 2017

Accepted $18^{\text {th }}$ May 2017

Published 20 ${ }^{\text {th }}$ July 2017

\begin{abstract}
The agronomic practices such as plant spacing and phosphate fertilizer requirements for the cultivation of Bambara groundnut [Vigna subterranea (L.) Verdc.] have not yet been fully determined in Agbani agro ecology South east Nigeria. Field trials were conducted in 2015 and 2016 planting season at the Teaching and Research Farm of the Faculty of Agriculture and Natural Resources Management, Enugu State University of Science and Technology, Agbani as a 4 x 3 factorial experiment in randomized complete block design with three replications. The treatments were four rates of single super phosphate fertilizer $\left(0 \mathrm{~kg} \mathrm{P} \mathrm{ha}^{-1}, 25 \mathrm{~kg} \mathrm{P} \mathrm{ha}^{-1}, 50 \mathrm{~kg} \mathrm{P} \mathrm{ha-1}\right.$ and $75 \mathrm{~kg}^{-1}$ $\mathrm{P} \mathrm{ha}^{-1}$ ) and three plant spacing regimes (intra and inter row spacing) $10 \mathrm{~cm} \times 45 \mathrm{~cm}(222,222$ plants hectare $\left.{ }^{-1}\right) 5 \mathrm{~cm} \times 45 \mathrm{~cm}\left(148,148\right.$ plants hectare $\left.{ }^{-1}\right)$ and $20 \mathrm{~cm} \times 45 \mathrm{~cm}(111,111$ plants hectare $\left.^{-1}\right)$. Soil samples were collected from the top soil at a depth of 0 to $15 \mathrm{~cm}$ before planting,
\end{abstract}


four and eight weeks after planting. The obtained results showed that Bambara groundnut spaced at $20 \mathrm{~cm} \times 45 \mathrm{~cm}$ per plant grown on plots fertilized with $75 \mathrm{~kg} \mathrm{P}^{-1}$ single super phosphate fertilizer (SSP) had significantly $(P=.05)$ the tallest plants $[24.53 \mathrm{~cm}$ at 4 weeks after planting (WAP), $35.23 \mathrm{~cm}$ at 8WAP in 2015 and $25.00 \mathrm{~cm}$ at 4 WAP and $36.00 \mathrm{~cm}$ at 8WAP in 2016 respectively] compared with the other treatments. The effects of single super phosphate fertilizer treatment on leaf area index (6.04 in 2015 at 4WAP, 45.86 in 2015 at 8WAP, 6.31 at 4WAP in 2016 and 46.51 at 8 WAP in 2016) were significant $(P=.05)$ at the highest at application rate of 75 $\mathrm{kg} \mathrm{P} \mathrm{ha}^{-1}$ of SSP. Plots which had the lowest population density $\left(111,111\right.$ plants hectare $\left.{ }^{-1}\right)$ and received the highest rate of $\operatorname{SSP}\left(75 \mathrm{~kg} \mathrm{P} \mathrm{ha}^{-1}\right)$ gave significantly $(P=.05)$ the highest number of fresh pods per plant at harvest (17.67 in 2015 and 19.00 in 2016) and weight of fresh pods per plant (248.03 g plant $^{-1}$ in 2015 and 290.76 plant $^{-1}$ in 2016 respectively) than the other treatments. Total nitrogen, phosphorus and potassium concentration 7 of soil were significantly $(P=.05)$ higher in plots which received $75 \mathrm{~kg} \mathrm{P} \mathrm{ha}^{-1} \mathrm{SSP}$ than the other treatments. Plant population density of 111,111 plants hectare ${ }^{-1}$ and SSP rate of $75 \mathrm{~kg} \mathrm{P}^{-1}$ is recommended for optimum agronomic performance of Bambara groundnut in a degraded tropical ultisol.

Keywords: Bambara groundnut; single super phosphate fertilizer; nodulation; plant spacing; ultisol.

\section{INTRODUCTION}

Bambara groundnut [Vigna subterranea (L.) Verdc.] represents the third most important grain legume in semi-arid Africa after cowpea (Vigna unguiculata) and groundnut (Arachis hypogaea) $[1,2]$. It is variously known as "izindlubu" (Zulu, South Africa); "Jugo beans" (South Africa); "Ntoyo cibemba" (Zambia); "Gurjiya" or "Kwaruru" (Hausa, Nigeria); "Okpa" (Igbo, Nigeria); "Epa- Roro" (Yoruba, Nigeria); "Nyimo beans" (Zimbabwe). Bambara groundnut seed contains $63 \%$ carbohydrate, $19 \%$ protein and $6.5 \%$ oil [3]. The gross energy value of Bambara groundnut seed is greater than that of other common pulses such as cowpea, lentil (Lens esculenta) and pigeon pea (Cajanus cajan) [4]. It is deficient in sulphur-containing amino acids [5], some genotypes contain higher amounts of methionine and lysine than are found in other legumes [6]. It is resistant to high temperature and is suitable for marginal soils where other leguminous crops cannot be grown [7]. Despite its nutritional value, it is still considered as one of the prioritized neglected and underutilized crop species in Nigeria [8].

In Agbani, soils are degraded ultisol characterized by low fertility and high acidity which may be caused by over exploitation, nutrient volatilization, erosion or leaching [9]. The agronomic practices such as plant spacing and phosphate fertilizer requirements for the cultivation of this crop have not yet been fully determined in Agbani agro ecology.

Phosphorus $(P)$ is the most important key element in the nutrition of plants, next to nitrogen
(N). It plays an important role in virtually all major metabolic processes in plant including photosynthesis, energy transfer, signal transduction, macromolecular biosynthesis and respiration [10]. It is abundantly available in soils in both organic and inorganic forms. The organic forms of $P$ are found in humus and other organic materials. The $P$ in organic materials are released through mineralization process involving soil organisms. The inorganic forms of $P$ exist as calcium phosphate (Ca-P), aluminum phosphate (Al-P), iron phosphate (Fe-P), reductant soluble phosphate (Red-P), Saloidbound phosphate (Sal-P), and occluded phosphate (Occ-P) [11]. Plants are unable to utilized phosphate because $95-99 \%$ phosphate are present inthe insoluble, immobilized, and precipitated form [12]. Plants absorb phosphate only in two soluble forms, the monobasic $\left(\mathrm{H}_{2} \mathrm{PO}_{4}\right)$ and the diabasic $\left(\mathrm{HPO}_{4}{ }^{2-}\right)$ ions. Legumes are phosphorus loving plants, they require phosphorus for growth, nodualation and seed development, and most especially in nitrogen fixation which is an energy driven process [13]. Investigations by [13], revealed that the highest application rate of single super phosphate fertilizer $\left(70 \mathrm{~kg} \mathrm{P} \mathrm{ha}^{-1}\right)$ increased the number of leaves per plant, number of branches per plant, plant height, leaf area index and weight of pod after harvest of Mucuna flagellipes in a degraded acid tropical ultisol. Careful application of phosphorus fertilizer to legumes must be geared towards enhancing not only their growth and yield, but also nitrogen fixation. In Nigeria, legumes do not receive any form of mineral phosphorus fertilizer, they therefore rely entirely on the naturally available soil phosphorus and other nutrients for nitrogen fixation and growth 
and this has resulted in lower yield and low nitrogen fixation by these legumes [13].

Maximum yield of a particular crop in a given environment can be obtained at spacing where competition among the plants is minimal. [14] observed that this can be achieved with optimum spacing which not only utilize soil moisture, nutrient, light and carbon dioxide more effectively but also avoids excessive competition among the plants. However, beyond certain limit yield cannot be increased with decreasing or increasing row spacing. Hence, optimum spacing induces the plant to achieve its potential yield. [15] and [16], indicated that cowpea plants produced better at the lowest densities, set more number of pods than those at the higher densities. Therefore, the general objective of this experiment is to determine the effects of phosphate fertilizer rates and plant spacing on biological nitrogen fixation, growth and yield of Bambara groundnut.

The specific objectives:

1. Determine the effects of single super phosphate fertilizer rates and plant spacing on nodulation, growth and yield on Bambara groundnut (Vigna subterranea).

2. Determine the effects of single super phosphate fertilizer rates and plant spacing on soil nutrient statues

\section{MATERIALS AND METHODS}

\subsection{Description of the Experimental Site}

This experiment was carried out in 2015 and 2016 planting season respectively at the Teaching and Research Farm of the Faculty of Agriculture and Natural Resources Management, Enugu State University of Science and Technology, Nigeria $\left(06^{\circ} 52^{\prime} \mathrm{N}, 07^{\circ} 15^{\prime} \mathrm{E}\right.$ and elevation $450 \mathrm{~m}$ above sea level) [17] The area has an annual rainfall which ranges from $1700-$ $2010 \mathrm{~mm}$. The rainfall pattern is bimodal and is between April and October, and the dry season is between November and March. The soil's textural class is sandy loam with an isohyperthermic soil temperature regime [17] and is classified as Typic Paleudults of the order Utisol [18].

\subsection{Experimental Design and Field Operations}

Field trials were conducted in 2015 and 2016 planting season at the Teaching and Research Farm of the Faculty of Agriculture and Natural Resources Management, Enugu State University of Science and Technology, Agbani as a $4 \times 3$ factorial experiment in randomized complete block design with three replications. The treatments were four rates of single super phosphate fertilizer $\left(0 \mathrm{~kg} \mathrm{P} \mathrm{ha}^{-1}, 25 \mathrm{~kg} \mathrm{P} \mathrm{ha}^{-1}, 50\right.$ $\mathrm{kg} \mathrm{P} \mathrm{ha}{ }^{-1}$ and $75 \mathrm{~kg} \mathrm{P} \mathrm{ha}^{-1}$ ) and three plant spacing regimes (intra and inter row spacing) 10 $\mathrm{cm} \times 45 \mathrm{~cm}\left(222,222\right.$ plants hectare $\left.{ }^{-1}\right) 5 \mathrm{~cm} \times 45$ $\mathrm{cm}\left(148,148\right.$ plants hectare $\left.{ }^{-1}\right)$ and $20 \mathrm{~cm} \times 45 \mathrm{~cm}$ $\left(111,111\right.$ plants hectare ${ }^{-1}$ ) (Table 1$)$. A total land area measuring $324 \mathrm{~m}^{2}(9 \mathrm{~m} \times 36 \mathrm{~m})$ was used for the experiment. The land was divided into three blocks (columns: north-south direction), and each was sub-divided into 12 plots (rows: east-west direction) making a total of thirty-six plots (Fig. 1). The plots (beds) measuring $2 \mathrm{~m} \times 2$ $\mathrm{m}\left(4 \mathrm{~m}^{2}\right)$ were separated by $1 \mathrm{~m} \times 1 \mathrm{~m}$ pathway between and in between plots. Planting was done at the rate of two seeds per hole using the plant spacing regimes as treatments and thinned to one plant at two weeks after planting (Fig. 2a-b). Prophylactic application of $15 \mathrm{ml}$ of Karate (Pyrethroid insecticide) in five liters of water was applied at one week after planting and at four, six and eight weeks after planting to avert pest incidence. Single super phosphate fertilizer was applied at 3 weeks after planting by binding method (2 $\mathrm{cm}$ away from the seedling). Three plants at the center rows were sampled during data collection. Weeding was done by using traditional hoe.

Table 1. Treatment combinations of four rates of single super phosphate fertilizer and three plant spacing regimes in a randomized complete block design

\begin{tabular}{llllll}
\hline & & \multicolumn{4}{c}{ Phosphate fertilizer rate (A) } \\
\cline { 2 - 6 } & & A1 & A2 & A3 & A4 \\
\hline \multirow{3}{*}{ Plant spacing (B) } & B1 & A1B1 & A2B1 & A3B1 & A4B1 \\
& B2 & A1B2 & A2B2 & A3B2 & A4B2 \\
& B3 & A1B3 & A2B3 & A3B3 & A4B3 \\
\hline
\end{tabular}

A1 - $0 \mathrm{~kg} P \mathrm{ha}^{-1}, A 2-25 \mathrm{~kg} P \mathrm{ha}^{-1}, A 3-50 \mathrm{~kg} \mathrm{P} \mathrm{ha}^{-1}, A 4-75 \mathrm{~kg} \mathrm{P} \mathrm{ha}^{-1}, \mathrm{B1}-10 \mathrm{~cm} \times 45 \mathrm{~cm}$ (222,222 plants hectare $\left.^{-1}\right), B 2-5 \mathrm{~cm} \times 45 \mathrm{~cm}\left(148,148\right.$ plants hectare $\left.{ }^{-1}\right), B 3-20 \mathrm{~cm} \times 45 \mathrm{~cm}\left(111,111\right.$ plants hectare $\left.{ }^{-1}\right)$ 


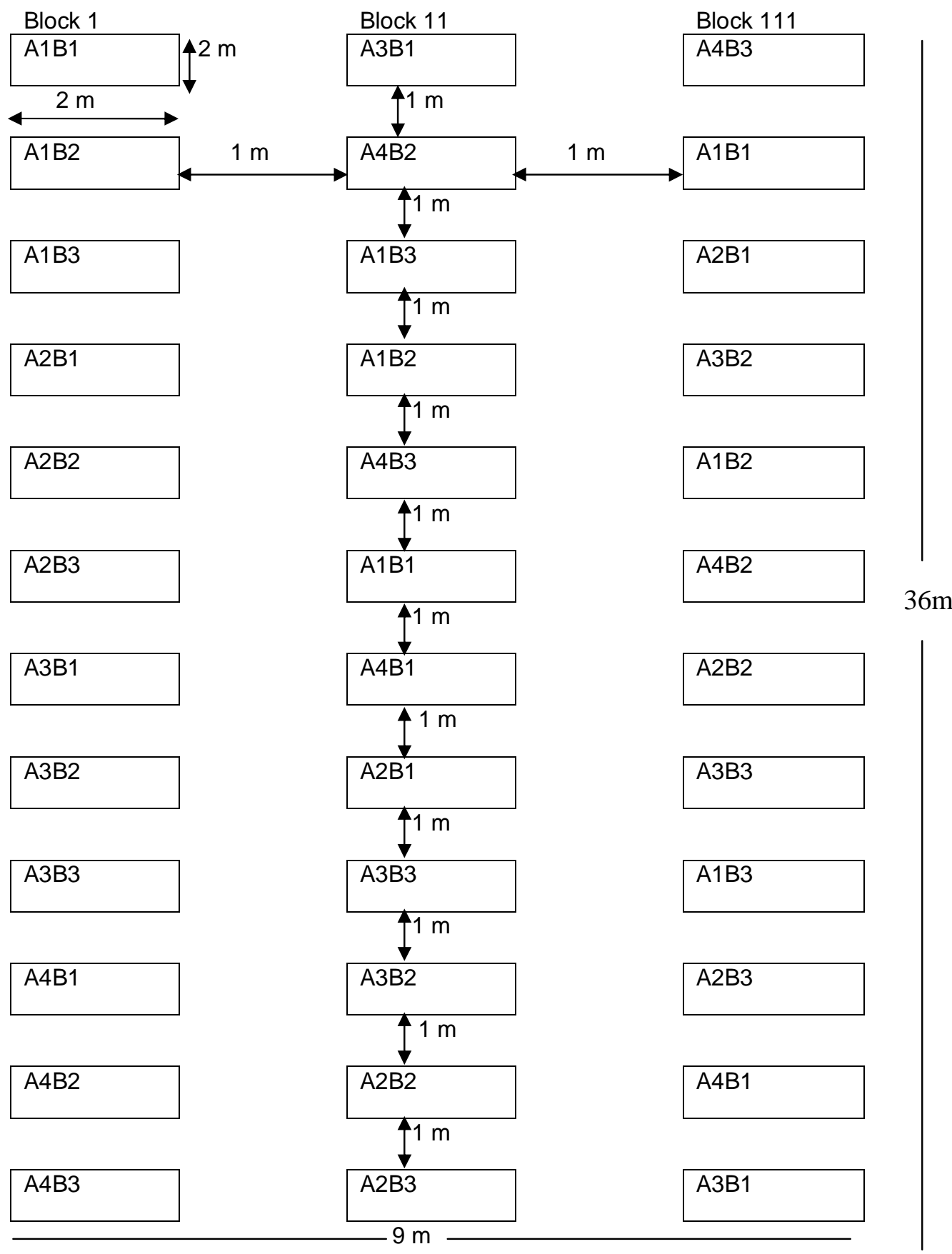

Fig. 1. Schematic illustration of the field layout design of the experiment

A1 - $0 \mathrm{~kg} \mathrm{P} \mathrm{ha} a^{-1}, A 2-25 \mathrm{~kg} \mathrm{Pha}{ }^{-1}, A 3-50 \mathrm{~kg} P \mathrm{ha}^{-1}, A 4-75 \mathrm{~kg} \mathrm{Pha}^{-1}, B 1-10 \mathrm{~cm} \times 45 \mathrm{~cm}(222,222$ plants hectare $\left.^{-1}\right), B 2-5 \mathrm{~cm} \times 45 \mathrm{~cm}\left(148,148\right.$ plants hectare- $\left.{ }^{-1}\right), B 3-20 \mathrm{~cm} \times 45 \mathrm{~cm}$ (111,111 plants hectare $\left.{ }^{-1}\right)$

\subsection{Soil Sample Collection and Analyses}

Soil samples were collected from the top soil at a depth of 0 to $15 \mathrm{~cm}$ before planting and at four and eight weeks after planting. Three representative soil samples were randomly collected per plot and bulked to form a composite soil sample for each plot. A total of thirty-six composite soil samples were collected. Samples were air dried, ground and passed through a 
sieve of $2 \mathrm{~mm}$ standard mesh size. The soil $\mathrm{pH}$ will be determined with a $\mathrm{pH}$ meter using 1:2.5 soil to water ratio and 1: 2.5 soil to $0.1 \mathrm{~N} \mathrm{KCl}$ (potassium chloride) suspension according to [19]. Organic carbon was determined using the Walkley and Black wet digestion method [20]. Soil organic matter content was obtained by multiplying the value of organic carbon by 1.724 (Van Bemmeler factor). Total nitrogen was determined by Micro-kjeldahl procedure [19]. Available phosphorus was extracted with Bray II extractant as described by [21] and determined colorimeterically using ascorbic acid method [22]. Exchangeable potassium was extracted using 1 ammonium acetate $\left(\mathrm{NH}_{4} \mathrm{OAC}\right)$ solution and determined by the flame emission spectroscopy as outlined by [23]. Aluminium and hydrogen content (exchangeable acidity) was determined by titrimetric method after extraction with $1.0 \mathrm{~N}$ $\mathrm{KCl}$ [24]. The cation exchange capacity was determined by $\mathrm{NH}_{4} \mathrm{OAC}$ displacement method [25]. Calcium and magnesium was determined by the complexiometric titration method as described by [26]. Particle size distribution analysis was done by the hydrometer method [27] and the corresponding textual class determined from the United State Department of Agriculture Soil Texture Triangle. Base saturation was determined by the method outlined by [19].

\subsection{Data Collection (Fig. 3a-c)}

Plant height was determined at four and eight weeks after planting by measuring the length of the plant from the soil level to the tip of the topmost leaf using a measuring tape. Leaf area per plant was estimated as leaf length $(L) x$ width (W) $\times 0.85$ as described by [28]. Leaf area index per plant was determined at four and eight weeks after planting as total leaf area per plant divided by the feeding area available for the plant (inter row spacing multiplied by intra row spacing of each plant) according to[29] and [30]. Number of nodules per plant was obtained at four and eight weeks after planting and number of fresh pods per plant was obtained from visual counting of nodules from uprooted Bambara groundnut. Fresh pods weight per plant was recorded at harvest using electronic weighing balance.

\subsection{Data Analysis}

Data collected were subjected to analysis of variance (ANOVA) test for randomized complete block design as outlined by [31] (Table 2). Significant means were separated using Fisher's least significant difference (F-LSD) at 5\% probability level. Statistical analysis was executed using [32] statistical software.

Table 2. Outline of analysis of variance of a 4 $\times 3$ factorial trial in a randomized complete block design

\begin{tabular}{lll}
\hline $\begin{array}{l}\text { Sources of } \\
\text { variation }\end{array}$ & $\begin{array}{l}\text { Degree of } \\
\text { freedom }\end{array}$ & $\begin{array}{l}\text { Degree of } \\
\text { freedom } \\
\text { specified }\end{array}$ \\
\hline Block $(R)$ & $(R-1)$ & 2 \\
$\begin{array}{l}\text { Phosphate } \\
\text { fertilizer rate }(A)\end{array}$ & $(A-1)$ & 3 \\
Plant spacing $(B)$ & $(B-1)$ & 2 \\
Interaction $(A B)$ & $(A-1)(B-1)$ & 6 \\
Error & $(A B-1)(R-1)$ & 22 \\
Total & $(A B R-1)$ & 35 \\
\hline
\end{tabular}

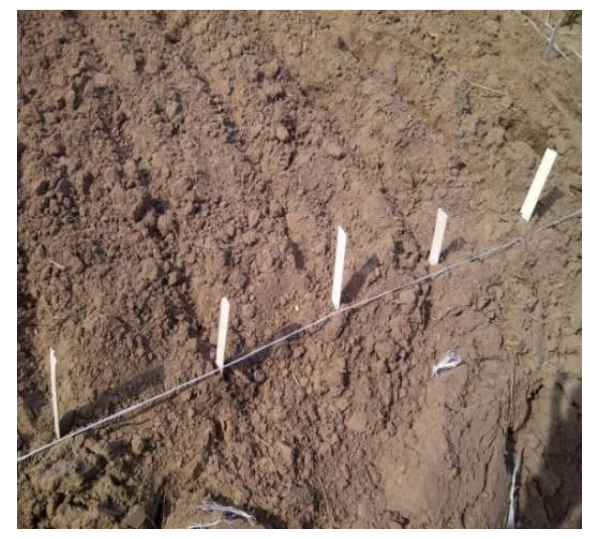

Fig. 2a. Marking out of the plant spacing treatments in the field

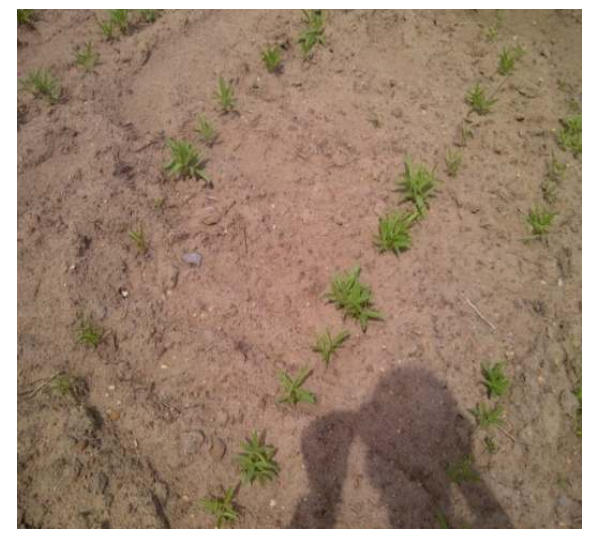

Fig. 2b. Bambara groundnut [Vigna subterranea (L.) Verdc.] seedlings after thinning

Fig. 2. Field operations before two weeks after planting 


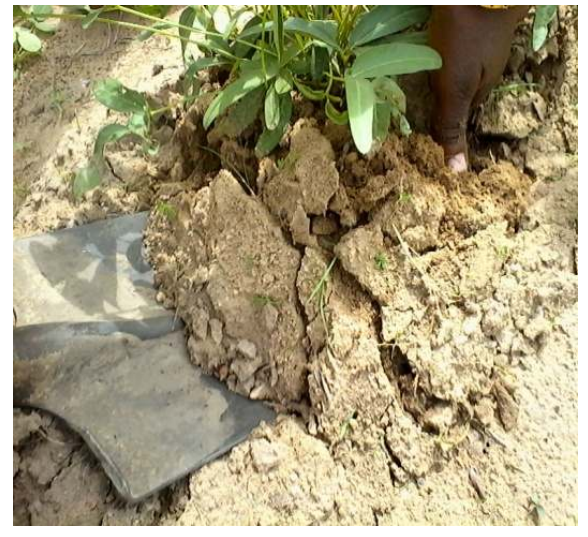

Fig. 3a. Uprooting Bambara groundnut [Vigna subterranea (L.) Verdc.] plant from the soil for nodule count

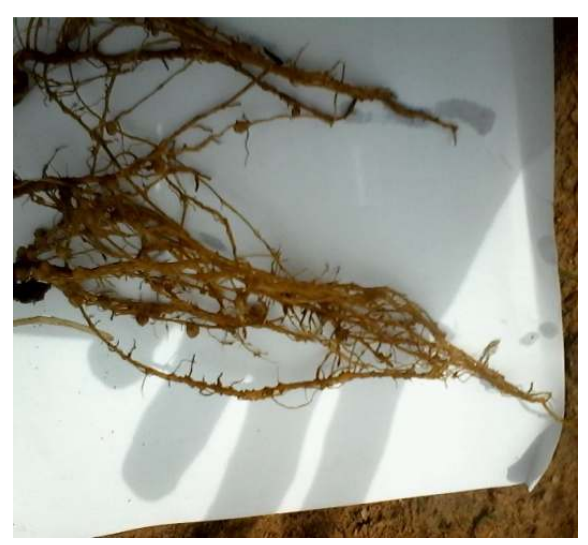

Fig. 3b. Nodule count

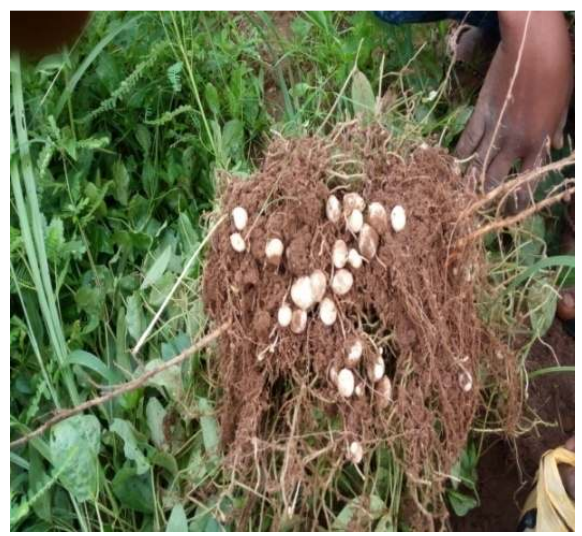

Fig. 3c. Fresh pods at harvest

Fig. 3. Plant data collection from the experimental field

Linear model used for the analysis of variance is shown below [31].

$$
X i j_{k}=\mu+A_{i}+B_{j}+R_{k}+(A B)_{i j}+€ i j_{k} .
$$

Where:

$X \mathrm{Xij}_{\mathrm{k}}=$ Any individual observation on the experiment unit.

$\mu \quad=$ population or general mean

$A_{i} \quad=$ Effects of phosphate fertilizer rates

$B_{j} \quad=$ Effects of plant spacing

$R_{k}=$ Effects of blocking

$(A B)_{i j}=$ Effects of phosphate fertilizer rates and plant spacing interaction

$€ \mathrm{ijk}=$ Experimental error.

\section{RESULTS AND DISCUSSION}

The data shown in Table 3 indicates that the soil of the study area before planting was acidic (pH6.1 and 5.4 in water and potassium chloride respectively in 2015 and 6.3 and 6.2 in water and potassium chloride, respectively in 2016). The soil textural class was loamy sand in 2015 and 2016 planting season, which contained 46\% (2015) and 47\% (2016) coarse sand, 41\% (2015) and $40 \%$ (2016) fine sand, 5\% (2015) and $5 \%(2016)$ clay and $8 \%(2015)$ and $8 \%(2016)$ silt. The organic carbon content was found to be $0.65 \%$ (2015) and $0.72 \%$ (2016), organic matter content was $1.32 \%(2015)$ and $1.24 \%$ (2016) and total nitrogen contents were $0.0057 \%$ (2015) and $0.0064 \%$ (2016). The exchangeable base [sodium $0.9 \mathrm{c} \mathrm{mol} \mathrm{kg}^{-1}$ (2015) and $0.8 \mathrm{c}$ mol kg ${ }^{-1}(2016)$, potassium $0.17 \mathrm{c} \mathrm{mol} \mathrm{kg}^{-1}$ (2015) and $0.16 \mathrm{c} \mathrm{mol} \mathrm{kg}^{-1}$ (2016) calcium $1.2 \mathrm{c} \mathrm{mol} \mathrm{kg}^{-1}$ (2015) and $1.0 \mathrm{c} \mathrm{mol} \mathrm{kg}^{-1}$ (2016) and magnesium $0.7 \mathrm{c} \mathrm{mol} \mathrm{kg}^{-1}$ (2015) and $0.9 \mathrm{c} \mathrm{mol} \mathrm{kg}^{-1}$ (2016).] The cation exchange capacity of the soil was 8.1 $\mathrm{c} \mathrm{mol} \mathrm{kg}{ }^{-1}$ (2015) and $7.0 \mathrm{c} \mathrm{mol} \mathrm{kg}^{-1}$ (2016) for the base saturation $46 \%$ (2015) and $44 \%$ (2016). The hydrogen $2.6 \mathrm{c} \mathrm{mol} \mathrm{kg}^{-1}(2015)$ and $2.4 \mathrm{c} \mathrm{mol}$ $\mathrm{kg}^{-1}$ (2016) and aluminum content was found to be $3.4 \mathrm{c} \mathrm{mol} \mathrm{kg}^{-1}(2015)$ and $3.6 \mathrm{c} \mathrm{mol} \mathrm{kg}^{-1}$ (2016) and available phosphorus (Bray 11) was found to be $7.9 \mathrm{c} \mathrm{mol} \mathrm{kg}^{-1}$ (2015) and $8.8 \mathrm{c} \mathrm{mol}$ $\mathrm{kg}^{-1}(2016)$

Bambara groundnut spaced at $20 \mathrm{~cm} \times 45 \mathrm{~cm}$ per plant grown on plots fertilized with $75 \mathrm{~kg} P$ $\mathrm{ha}^{-1}$ single super phosphate fertilizer (SSP) had significantly $(P=.05)$ the tallest plants $[24.53 \mathrm{~cm}$ at 4 weeks after planting (WAP), $35.23 \mathrm{~cm}$ at $8 \mathrm{WAP}$ in 2015 and $25.00 \mathrm{~cm}$ at $4 \mathrm{WAP}$ and 36.00 $\mathrm{cm}$ at $8 \mathrm{WAP}$ in 2016 respectively] compared with the other treatments (Table 4). This outcome suggest that plants grown on lower population density had enough resources and competed less for factors such as sunlight, moisture and 
nutrients necessary for growth. This findings tallied with what [13] reported that the highest plant height of Mucuna flagellipes were obtained on plots treated with $70 \mathrm{~kg} \mathrm{P} \mathrm{ha}^{-1}$ of SSP in an ultisol. Similarly, these results corrobated [33] who reported that $75 \mathrm{~kg} \mathrm{P} \mathrm{ha}^{-1}$ of SSP gave the height plant height of Bambara groundnut in Calaber south east Nigeria.

Table 5 reveals that the effects of single super phosphate fertilizer treatment on leaf area index (6.04 in 2015 at 4WAP, 45.86 in2015 at 8WAP, 6.31 at $4 \mathrm{WAP}$ in 2016 and 46.51 at $8 \mathrm{WAP}$ in 2016) were significant $(P=.05)$ at the highest at application rate of $75 \mathrm{~kg} \mathrm{P}^{-1}$ of SSP. More so, Bambara groundnut [Vigna subterranea (L.) Verdc.] which were grown on spacing of $10 \mathrm{~cm} \times$ $45 \mathrm{~cm}\left(222,222\right.$ plants hectare $\left.{ }^{-1}\right)$ had the highest leaf area index at 4WAP (4.19 in 2015) and at a spacing of $20 \mathrm{~cm} \times 45 \mathrm{~cm}(111,111$ plants hectare $^{-1}$ ) at 8WAP in 2015 and at 4WAP (4.40 in 2016) and at a spacing of $20 \mathrm{~cm} \times 45 \mathrm{~cm}$ at 8WAP (29.30 in 2016) compared with other plant spacing in 2015 and 2016 planting season respectively. Bambara groundnut spaced at 10 $\mathrm{cm} \times 45 \mathrm{~cm}$ grown on plots which received $75 \mathrm{~kg}$ $\mathrm{P} \mathrm{ha}^{-1}$ of SSP had the highest leaf area index at
4WAP (7.69 in 2015) and a spacing of $20 \mathrm{~cm} \times$ $45 \mathrm{~cm}$ at 8WAP gave the highest (81.33) leaf area index in 2015. Similarly, the same trend was observed in 2016 planting season. This increase in leaf area index as plant population increased corroborated the findings by [34] and [35].

The results presented in Table 6 , shows that the combined effects of $75 \mathrm{~kg} \mathrm{P}^{-1}$ of SSP and 20 $\mathrm{cm} \times 45 \mathrm{~cm}$ plant spacing gave more number of nodules per plant $(40.33$ at $4 \mathrm{WAP}$ and 81.33 at 8 WAP in 2015 and 40.90 at 4WAP and 82.00 at $8 W A P$ in 2016 respectively). The effect of the highest $\left(75 \mathrm{~kg} \mathrm{P}^{-1}\right.$ ) rate of single super phosphate on number of nodules per plant of Bambara groundnut at 4WAP (37.33 in 2015 and 38.53 in 2016) and at 8WAP (75.89 in 2015 and 76.73 in 2016) were highest. Phosphorus plays an important role in virtually all major metabolic processes in plant including photosynthesis, energy transfer, signal transduction, macromolecular biosynthesis and respiration [10]. Legumes are phosphorus loving plants, they require phosphorus for growth, nodualation and seed development, and most especially in nitrogen fixation which is an energy driving process [13].

Table 3. Initial soil characteristics before planting in 2015 and 2016 cropping season

\begin{tabular}{|c|c|c|}
\hline Parameters & 2015 & 2016 \\
\hline \multicolumn{3}{|l|}{ Particle size distribution (\%) } \\
\hline Coarse sand & 46 & 47 \\
\hline Fine sand & 41 & 40 \\
\hline Clay & 5 & 5 \\
\hline Silt & 8 & 8 \\
\hline Textural class & Loamy sand & Loamy sand \\
\hline $\mathrm{pH}$ (water) & 6.1 & 6.3 \\
\hline $\mathrm{pH}(\mathrm{KCl})$ & 5.4 & 6.2 \\
\hline Organic carbon (\%) & 0.65 & 0.72 \\
\hline Organic matter (\%) & 1.32 & 1.24 \\
\hline Total nitrogen (\%) & 0.0057 & 0.0064 \\
\hline Available phosphorus $\left(\mathrm{c} \mathrm{mol} \mathrm{kg}^{-1}\right)$ & 7.9 & 8.8 \\
\hline \multicolumn{3}{|l|}{ Exchangeable bases $\left(\mathrm{c} \mathrm{mol} \mathrm{kg}{ }^{-1}\right)$} \\
\hline Calcium & 1.2 & 1.0 \\
\hline Magnesium & 0.7 & 0.9 \\
\hline Potassium & 0.17 & 0.16 \\
\hline Sodium & 0.9 & 0.8 \\
\hline \multicolumn{3}{|l|}{ Exchangeable acidity (c mol kg-1) } \\
\hline Hydrogen & 2.6 & 2.4 \\
\hline Aluminum & 3.2 & 3.6 \\
\hline Cation exchangeable capacity (c mol kg${ }^{-1}$ ) & 8.1 & 7.0 \\
\hline Base saturation (\%) & 46 & 44 \\
\hline
\end{tabular}


Table 4. Effect of single super phosphate fertilizer rate and plant spacing on plant height $(\mathrm{cm})$ of Bambara groundnut [Vigna subterranea (L.) Verdc.] at four and eight weeks after planting

\begin{tabular}{|c|c|c|c|c|c|c|c|c|}
\hline \multirow[t]{4}{*}{ SSP rate $\left(\mathrm{Kg} \mathrm{ha}^{-1}\right)(\mathrm{B})$} & \multicolumn{8}{|c|}{2015} \\
\hline & \multicolumn{8}{|c|}{ Plant spacing (A) } \\
\hline & \multicolumn{3}{|c|}{ 4WAP } & \multicolumn{5}{|c|}{ 8WAP } \\
\hline & $10 \mathrm{~cm} \times 45 \mathrm{~cm}$ & $15 \mathrm{~cm} \times 45 \mathrm{~cm}$ & $20 \mathrm{~cm} \times 45 \mathrm{~cm}$ & Mean (B) & $10 \mathrm{~cm} \times 45 \mathrm{~cm}$ & $15 \mathrm{~cm} \times 45 \mathrm{~cm}$ & $20 \mathrm{~cm} \times 45 \mathrm{~cm}$ & Mean (B) \\
\hline 0 & 13.96 & 15.36 & 16.00 & 15.11 & 18.96 & 19.83 & 21.53 & 20.11 \\
\hline 25 & 17.33 & 18.17 & 18.90 & 18.13 & 22.53 & 24.00 & 25.50 & 24.01 \\
\hline 50 & 19.96 & 20.73 & 21.30 & 20.66 & 27.93 & 29.26 & 30.70 & 29.30 \\
\hline 75 & 22.66 & 23.53 & 24.53 & 23.57 & 31.63 & 34.33 & 35.23 & 33.73 \\
\hline \multirow[t]{2}{*}{ Mean $(\mathrm{A})$} & 18.48 & 19.45 & 20.18 & 19.37 & 25.26 & 26.86 & 28.24 & 26.79 \\
\hline & & & 4WAP & & & 8WAP & & \\
\hline \multirow{3}{*}{\multicolumn{2}{|c|}{$\begin{array}{l}\text { F-LSD }_{(0.05)} \text { for any } 2 \text { plant spacing } \\
\text { F-LSD } \\
\text { F-LSD }_{(0.05)} \text { for any } 2 \text { SSP rate } \\
\end{array}$}} & & 0.62 & & & 1.11 & & \\
\hline & & & 1.91 & & & 2.00 & & \\
\hline & & & 5.22 & & & 6.34 & & \\
\hline \multirow[t]{4}{*}{ SSP rate $\left(\mathrm{Kg} \mathrm{ha}^{-1}\right)(\mathrm{B})$} & \multicolumn{8}{|c|}{2016} \\
\hline & \multicolumn{8}{|c|}{ Plant spacing (A) } \\
\hline & \multicolumn{4}{|c|}{ 4WAP } & \multicolumn{4}{|c|}{ 8WAP } \\
\hline & $10 \mathrm{~cm} \times 45 \mathrm{~cm}$ & $15 \mathrm{~cm} \times 45 \mathrm{~cm}$ & $20 \mathrm{~cm} \times 45 \mathrm{~cm}$ & Mean (B) & $10 \mathrm{~cm} \times 45 \mathrm{~cm}$ & $15 \mathrm{~cm} \times 45 \mathrm{~cm}$ & $20 \mathrm{~cm} \times 45 \mathrm{~cm}$ & Mean (B) \\
\hline 0 & 14.69 & 14.90 & 16.97 & 15.52 & 19.00 & 20.19 & 22.67 & 20.62 \\
\hline 25 & 19.43 & 20.00 & 19.00 & 19.48 & 22.90 & 24.50 & 26.70 & 24.70 \\
\hline 50 & 21.67 & 21.98 & 22.49 & 22.05 & 28.10 & 30.22 & 32.87 & 30.40 \\
\hline 75 & 22.90 & 24.78 & 25.00 & 24.23 & 31.99 & 35.18 & 36.00 & 34.39 \\
\hline \multirow[t]{2}{*}{$\operatorname{Mean}(\mathrm{A})$} & 19.67 & 20.42 & 20.87 & 20.32 & 25.50 & 27.52 & 29.56 & 27.53 \\
\hline & & & 4WAP & & & 8WAP & & \\
\hline \multirow{3}{*}{\multicolumn{2}{|c|}{$\begin{array}{l}\text { F-LSD }_{(0.05)} \text { for any } 2 \text { plant spacing } \\
\text { F-LSD } \\
\text { F-LSD }_{(0.05)} \text { for any } 2 \text { SSP rate } \\
\end{array}$}} & & 0.23 & & & 1.04 & & \\
\hline & & & 1.05 & & & 3.17 & & \\
\hline & & & 6.01 & & & 7.03 & & \\
\hline
\end{tabular}

WAWAP - Weeks after planting, F-LSD(0.05) - Fisher's least significant difference at 0.05 probability level, SSP - Single super phosphate fertilizer 
Table 5. Effect of single super phosphate fertilizer rate and plant spacing on leaf area index per plant of Bambara groundnut [Vigna subterranea (L.) Verdc.] at four and eight weeks after planting

\begin{tabular}{|c|c|c|c|c|c|c|c|c|}
\hline \multirow[t]{4}{*}{ SSP rate $\left(\mathrm{Kg} \mathrm{ha}^{-1}\right)(\mathrm{B})$} & \multicolumn{8}{|c|}{2015} \\
\hline & \multicolumn{8}{|c|}{ Plant spacing (A) } \\
\hline & \multicolumn{4}{|c|}{ 4WAP } & \multicolumn{4}{|c|}{ 8WAP } \\
\hline & $10 \mathrm{~cm} \times 45 \mathrm{~cm}$ & $15 \mathrm{~cm} \times 45 \mathrm{~cm}$ & $20 \mathrm{~cm} \times 45 \mathrm{~cm}$ & Mean (B) & $10 \mathrm{~cm} \times 45 \mathrm{~cm}$ & $15 \mathrm{~cm} \times 45 \mathrm{~cm}$ & $20 \mathrm{~cm} \times 45 \mathrm{~cm}$ & Mean (B) \\
\hline 0 & 1.73 & 1.43 & 1.23 & 1.46 & 7.93 & 7.12 & 7.90 & 7.65 \\
\hline 25 & 2.50 & 2.00 & 1.94 & 2.15 & 16.37 & 12.53 & 11.30 & 13.40 \\
\hline 50 & 4.84 & 4.00 & 3.48 & 4.11 & 29.61 & 17.26 & 16.27 & 21.05 \\
\hline 75 & 7.69 & 5.73 & 4.71 & 6.04 & 30.46 & 25.83 & 81.33 & 45.86 \\
\hline \multirow[t]{2}{*}{ Mean $(A)$} & 4.19 & 3.29 & 2.84 & 3.44 & 21.09 & 15.69 & 29.20 & 21.99 \\
\hline & & & 4WAP & & & 8WAP & & \\
\hline \multirow{3}{*}{\multicolumn{2}{|c|}{$\begin{array}{l}\text { F-LSD }_{(0.05)} \text { for any } 2 \text { plant spacing } \\
\text { F-LSD } \\
\text { F-LSD } \\
(0.05) \\
\text { for any } 2 \text { SSP rate } \\
\text { for } 2 \mathrm{~A} \text { X B }\end{array}$}} & & 0.30 & & & 3.46 & & \\
\hline & & & 0.50 & & & 4.77 & & \\
\hline & & & 0.02 & & & 0.72 & & \\
\hline \multirow[t]{4}{*}{ SSP rate $\left(\mathrm{Kg} \mathrm{ha}^{-1}\right)(\mathrm{B})$} & \multicolumn{8}{|c|}{2016} \\
\hline & \multicolumn{8}{|c|}{ Plant spacing (A) } \\
\hline & \multicolumn{4}{|c|}{ 4WAP } & \multicolumn{4}{|c|}{ 8WAP } \\
\hline & $10 \mathrm{~cm} \times 45 \mathrm{~cm}$ & $15 \mathrm{~cm} \times 45 \mathrm{~cm}$ & $20 \mathrm{~cm} \times 45 \mathrm{~cm}$ & Mean (B) & $10 \mathrm{~cm} \times 45 \mathrm{~cm}$ & $15 \mathrm{~cm} \times 45 \mathrm{~cm}$ & $20 \mathrm{~cm} \times 45 \mathrm{~cm}$ & Mean (B) \\
\hline 0 & 1.88 & 1.69 & 1.34 & 1.64 & 8.95 & 6.52 & 6.11 & 7.19 \\
\hline 25 & 2.80 & 2.20 & 2.00 & 2.33 & 16.77 & 12.93 & 11.98 & 13.89 \\
\hline 50 & 5.00 & 4.12 & 3.67 & 4.26 & 30.37 & 18.11 & 16.90 & 21.79 \\
\hline 75 & 7.90 & 6.14 & 4.90 & 6.31 & 31.13 & 26.18 & 82.21 & 46.51 \\
\hline \multirow[t]{2}{*}{ Mean $(A)$} & 4.40 & 3.54 & 2.98 & 3.64 & 21.81 & 15.94 & 29.30 & 22.35 \\
\hline & & & 4WAP & & & 8WAP & & \\
\hline \multirow{3}{*}{\multicolumn{2}{|c|}{$\begin{array}{l}\text { F-LSD } \\
\text { F-LSD } \\
\text { F-LS) }_{(0.05)} \text { for any } 2 \text { plant spacing } 2 \text { SSP rate } \\
\text { FSD } \\
(0.05)\end{array}$}} & & 0.03 & & & 4.16 & & \\
\hline & & & 0.01 & & & 5.17 & & \\
\hline & & & 0.11 & & & 0.10 & & \\
\hline
\end{tabular}


Table 6. Effect of single super phosphate fertilizer rate and plant spacing on number of nodules per plant of Bambara groundnut [Vigna subterranea (L.) Verdc.] at four and eight weeks after planting

\begin{tabular}{|c|c|c|c|c|c|c|c|c|}
\hline \multirow[t]{4}{*}{ SSP rate $\left(\mathrm{Kg} \mathrm{ha}^{-1}\right)(\mathrm{B})$} & \multicolumn{8}{|c|}{2015} \\
\hline & \multicolumn{8}{|c|}{ Plant spacing (A) } \\
\hline & \multicolumn{4}{|c|}{ 4WAP } & \multicolumn{4}{|c|}{ 8WAP } \\
\hline & $10 \mathrm{~cm} \times 45 \mathrm{~cm}$ & $15 \mathrm{~cm} \times 45 \mathrm{~cm}$ & $20 \mathrm{~cm} \times 45 \mathrm{~cm}$ & Mean (B) & $10 \mathrm{~cm} \times 45 \mathrm{~cm}$ & $15 \mathrm{~cm} \times 45 \mathrm{~cm}$ & $20 \mathrm{~cm} \times 45 \mathrm{~cm}$ & Mean (B) \\
\hline 0 & 16.33 & 17.00 & 18.33 & 17.21 & 44.67 & 47.00 & 47.67 & 46.45 \\
\hline 25 & 19.33 & 20.00 & 22.33 & 20.55 & 49.00 & 49.67 & 51.67 & 50.11 \\
\hline 50 & 25.00 & 26.33 & 30.00 & 27.11 & 56.00 & 62.67 & 67.00 & 61.89 \\
\hline 75 & 34.00 & 37.67 & 40.33 & 37.33 & 70.67 & 75.67 & 81.33 & 75.89 \\
\hline \multirow[t]{2}{*}{ Mean $(A)$} & 23.67 & 25.25 & 27.75 & 25.56 & 55.09 & 58.75 & 61.92 & 58.59 \\
\hline & \multicolumn{5}{|c|}{ 4WAP } & \multicolumn{3}{|l|}{ 8WAP } \\
\hline \multirow{3}{*}{\multicolumn{2}{|c|}{$\begin{array}{l}\text { F-LSD }_{(0.05)} \text { for any } 2 \text { plant spacing } \\
\text { F-LSD }_{(0.05)} \text { for any } 2 \text { SSP rate } \\
\text { F-LSD }_{(0.05)} \text { for any } 2 \text { A X B }\end{array}$}} & & 1.01 & & & 1.01 & & \\
\hline & & & 1.32 & & & 2.73 & & \\
\hline & & & 1.00 & & & 6.23 & & \\
\hline \multirow[t]{4}{*}{ SSP rate $\left(\mathrm{Kg} \mathrm{ha}^{-1}\right)(\mathrm{B})$} & \multicolumn{8}{|c|}{2016} \\
\hline & \multicolumn{8}{|c|}{ Plant spacing (A) } \\
\hline & \multicolumn{4}{|c|}{ 4WAP } & \multicolumn{4}{|c|}{ 8WAP } \\
\hline & $10 \mathrm{~cm} \times 45 \mathrm{~cm}$ & $15 \mathrm{~cm} \times 45 \mathrm{~cm}$ & $20 \mathrm{~cm} \times 45 \mathrm{~cm}$ & Mean (B) & $10 \mathrm{~cm} \times 45 \mathrm{~cm}$ & $15 \mathrm{~cm} \times 45 \mathrm{~cm}$ & $20 \mathrm{~cm} \times 45 \mathrm{~cm}$ & Mean (B) \\
\hline 0 & 17.00 & 17.78 & 19.10 & 17.96 & 44.90 & 48.11 & 49.16 & 47.39 \\
\hline 25 & 19.98 & 20.51 & 22.93 & 21.14 & 49.99 & 50.34 & 52.33 & 50.89 \\
\hline 50 & 25.99 & 26.89 & 31.00 & 27.96 & 57.10 & 66.13 & 68.00 & 63.74 \\
\hline 75 & 34.78 & 39.90 & 40.90 & 38.53 & 70.98 & 77.22 & 82.00 & 76.73 \\
\hline \multirow[t]{2}{*}{ Mean $(A)$} & 24.44 & 26.27 & 28.48 & 26.40 & 55.74 & 60.45 & 62.87 & 59.69 \\
\hline & & & 4WAP & & & 8WAP & & \\
\hline \multirow{3}{*}{\multicolumn{2}{|c|}{$\begin{array}{l}\text { F-LSD }_{(0.05)} \text { for any } 2 \text { plant spacing } \\
\text { F-LSD }_{(0.05)} \text { for any } 2 \text { SSP rate } \\
\text { F-LSD }_{(0.05)} \text { for any } 2 \text { A X B }\end{array}$}} & & 0.87 & & & 1.11 & & \\
\hline & & & 0.02 & & & 2.34 & & \\
\hline & & & 0.01 & & & 2.57 & & \\
\hline
\end{tabular}

WAWAP - Weeks after planting, F-LSD $(0.05)$ - Fisher's least significant difference at 0.05 probability level, SSP - Single super phosphate fertilizer 
Table 7. Effects of single super phosphate fertilizer rate and plant spacing on number of fresh pods per plant and weight of fresh pods per plant of Bambara groundnut [Vigna subterranea (L.) Verdc.] at harvest

\begin{tabular}{|c|c|c|c|c|c|c|c|c|}
\hline \multirow[t]{4}{*}{ SSP rate $\left(\mathrm{Kg} \mathrm{ha}^{-1}\right)(\mathrm{B})$} & \multicolumn{8}{|c|}{2015} \\
\hline & \multicolumn{8}{|c|}{ Plant spacing (A) } \\
\hline & \multicolumn{4}{|c|}{ Number of fresh pods per plant } & \multicolumn{4}{|c|}{ Weight of fresh pods per plant (g plant $\left.{ }^{-1}\right)$} \\
\hline & $10 \mathrm{~cm} \times 45 \mathrm{~cm}$ & $15 \mathrm{~cm} \times 45 \mathrm{~cm}$ & $20 \mathrm{~cm} \times 45 \mathrm{~cm}$ & Mean (B) & $10 \mathrm{~cm} \times 45 \mathrm{~cm}$ & $15 \mathrm{~cm} \times 45 \mathrm{~cm}$ & $20 \mathrm{~cm} \times 45 \mathrm{~cm}$ & Mean (B) \\
\hline 0 & 6.33 & 7.33 & 8.00 & 7.22 & 66.41 & 85.27 & 109.16 & 86.95 \\
\hline 25 & 9.33 & 10.00 & 10.00 & 9.78 & 160.07 & 188.59 & 190.25 & 179.64 \\
\hline 50 & 12.33 & 13.00 & 15.00 & 13.44 & 206.91 & 217.46 & 227.53 & 217.30 \\
\hline 75 & 16.33 & 17.00 & 17.67 & 17.00 & 238.23 & 243.65 & 248.03 & 243.30 \\
\hline \multirow[t]{2}{*}{$\operatorname{Mean}(\mathrm{A})$} & 11.08 & 11.83 & 12.67 & 11.86 & 167.91 & 183.74 & 193.74 & 181.80 \\
\hline & \multicolumn{4}{|c|}{ Number of fresh pods per plant } & \multicolumn{4}{|c|}{ Weight of fresh pods per plant $\left(\mathrm{g} \mathrm{plant}^{-1}\right)$} \\
\hline \multirow{3}{*}{\multicolumn{2}{|c|}{$\begin{array}{l}\text { F-LSD }_{(0.05)} \text { for any } 2 \text { plant spacing } \\
\text { F-LSD }_{(0.05)} \text { for any } 2 \text { SSP rate } \\
\text { F-LSD }_{(0.05)} \text { for any } 2 \mathrm{~A} \times \mathrm{B}\end{array}$}} & 0.01 & & & 10.50 & & & \\
\hline & & 0.10 & & & 11.00 & & & \\
\hline & & 0.70 & & & 14.29 & & & \\
\hline \multirow[t]{4}{*}{ SSP rate $\left(\mathrm{Kg} \mathrm{ha}^{-1}\right)(\mathrm{B})$} & \multicolumn{8}{|c|}{2016} \\
\hline & \multicolumn{8}{|c|}{ Plant spacing (A) } \\
\hline & \multicolumn{4}{|c|}{ Number of fresh pods per plant } & \multicolumn{4}{|c|}{ Weight of fresh pods per plant $\left(\mathrm{g} \mathrm{plant}^{-1}\right)$} \\
\hline & $10 \mathrm{~cm} \times 45 \mathrm{~cm}$ & $15 \mathrm{~cm} \times 45 \mathrm{~cm}$ & $20 \mathrm{~cm} \times 45 \mathrm{~cm}$ & Mean (B) & $10 \mathrm{~cm} \times 45 \mathrm{~cm}$ & $15 \mathrm{~cm} \times 45 \mathrm{~cm}$ & $20 \mathrm{~cm} \times 45 \mathrm{~cm}$ & Mean (B) \\
\hline 0 & 7.00 & 8.17 & 9.54 & 8.24 & 70.18 & 89.34 & 150.33 & 103.28 \\
\hline 25 & 10.14 & 12.11 & 12.14 & 11.46 & 170.89 & 196.23 & 230.67 & 199.26 \\
\hline 50 & 12.99 & 14.80 & 16.18 & 14.66 & 217.71 & 220.00 & 267.49 & 235.07 \\
\hline 75 & 17.86 & 18.75 & 19.00 & 18.53 & 240.18 & 255.00 & 290.76 & 261.98 \\
\hline \multirow[t]{2}{*}{$\operatorname{Mean}(\mathrm{A})$} & 12.00 & 13.46 & 14.22 & 13.23 & 174.74 & 190.14 & 234.81 & 199.90 \\
\hline & \multicolumn{4}{|c|}{ Number of fresh pods per plant } & \multicolumn{4}{|c|}{ Weight of fresh pods per plant } \\
\hline \multirow{3}{*}{\multicolumn{2}{|c|}{$\begin{array}{l}\text { F-LSD } \\
\text { F-LSD }_{(0.05)} \text { for any } 2 \text { plant spacing } \\
\text { F-LSD }_{(0.05)} \text { for any } 2 \text { A X B B }\end{array}$}} & 0.22 & & & 12.94 & & & \\
\hline & & 2.91 & & & 19.00 & & & \\
\hline & & 0.92 & & & 22.11 & & & \\
\hline
\end{tabular}


Ikenganyia et al.; IJPSS, 17(4): 1-17, 2017; Article no.IJPSS.32606

Table 8. Effect of single super phosphate fertilizer rate and plant spacing on Nitrogen (\%) content of soil at four and eight weeks after planting

\begin{tabular}{|c|c|c|c|c|c|c|c|c|}
\hline \multirow[t]{4}{*}{ SSP rate $\left(\mathrm{Kg} \mathrm{ha}^{-1}\right)(\mathrm{B})$} & \multicolumn{8}{|c|}{2015} \\
\hline & \multicolumn{8}{|c|}{ Plant spacing (A) } \\
\hline & \multicolumn{4}{|c|}{ 4WAP } & \multicolumn{4}{|c|}{ 8WAP } \\
\hline & $10 \mathrm{~cm} \times 45 \mathrm{~cm}$ & $15 \mathrm{~cm} \times 45 \mathrm{~cm}$ & $20 \mathrm{~cm} \times 45 \mathrm{~cm}$ & Mean (B) & $10 \mathrm{~cm} \times 45 \mathrm{~cm}$ & $15 \mathrm{~cm} \times 45 \mathrm{~cm}$ & $20 \mathrm{~cm} \times 45 \mathrm{~cm}$ & Mean (B) \\
\hline 0 & 0.03 & 0.03 & 0.03 & 0.03 & 0.02 & 0.02 & 0.02 & 0.02 \\
\hline 25 & 0.03 & 0.04 & 0.04 & 0.04 & 0.02 & 0.03 & 0.03 & 0.03 \\
\hline 50 & 0.04 & 0.05 & 0.05 & 0.05 & 0.03 & 0.04 & 0.04 & 0.04 \\
\hline 75 & 0.05 & 0.06 & 0.06 & 0.06 & 0.05 & 0.05 & 0.05 & 0.05 \\
\hline \multirow[t]{2}{*}{ Mean $(A)$} & 0.04 & 0.05 & 0.05 & 0.05 & 0.03 & 0.04 & 0.04 & 0.04 \\
\hline & & & 4WAP & & & 8WAP & & \\
\hline \multirow{3}{*}{\multicolumn{2}{|c|}{$\begin{array}{l}\text { F-LSD }_{(0.05)} \text { for any } 2 \text { plant spacing } \\
\text { F-LSD } \\
\text { F-LSD }_{(0.05)} \text { for any } 2 \text { SSP rate } 2 \mathrm{~A} \times \mathrm{B}\end{array}$}} & & 0.001 & & & 0.001 & & \\
\hline & & & 0.001 & & & 0.001 & & \\
\hline & & & 0.001 & & & 0.001 & & \\
\hline \multirow[t]{4}{*}{ SSP rate $\left(\mathrm{Kg} \mathrm{ha}^{-1}\right)(\mathrm{B})$} & \multicolumn{8}{|c|}{2016} \\
\hline & \multicolumn{8}{|c|}{ Plant spacing (A) } \\
\hline & \multicolumn{4}{|c|}{ 4WAP } & \multicolumn{4}{|c|}{ 8WAP } \\
\hline & $10 \mathrm{~cm} \times 45 \mathrm{~cm}$ & $15 \mathrm{~cm} \times 45 \mathrm{~cm}$ & $20 \mathrm{~cm} \times 45 \mathrm{~cm}$ & Mean (B) & $10 \mathrm{~cm} \times 45 \mathrm{~cm}$ & $15 \mathrm{~cm} \times 45 \mathrm{~cm}$ & $20 \mathrm{~cm} \times 45 \mathrm{~cm}$ & Mean (B) \\
\hline 0 & 0.04 & 0.04 & 0.05 & 0.04 & 0.03 & 0.03 & 0.04 & 0.03 \\
\hline 25 & 0.04 & 0.04 & 0.05 & 0.04 & 0.03 & 0.03 & 0.04 & 0.03 \\
\hline 50 & 0.05 & 0.05 & 0.06 & 0.05 & 0.03 & 0.04 & 0.04 & 0.04 \\
\hline 75 & 0.05 & 0.06 & 0.07 & 0.06 & 0.04 & 0.05 & 0.04 & 0.04 \\
\hline \multirow[t]{2}{*}{ Mean $(A)$} & 0.05 & 0.05 & 0.06 & 0.05 & 0.03 & 0.04 & 0.04 & 0.04 \\
\hline & & & 4WAP & & & 8WAP & & \\
\hline \multirow{3}{*}{\multicolumn{3}{|c|}{$\begin{array}{l}\text { F-LSD }_{(0.05)} \text { for any } 2 \text { plant spacing } \\
\text { F-LSD } \\
\text { F-LSD }_{(0.05)} \text { for any } 2 \text { SSP rate } 2 \mathrm{~A} \times \mathrm{B}\end{array}$}} & 0.001 & & & 0.001 & & \\
\hline & & & 0.001 & & & 0.001 & & \\
\hline & & & 0.001 & & & 0.001 & & \\
\hline
\end{tabular}


Table 9. Effect of single super phosphate fertilizer rate and plant spacing on phosphorus (c mol kg-1) content of soil at four and eight weeks after planting

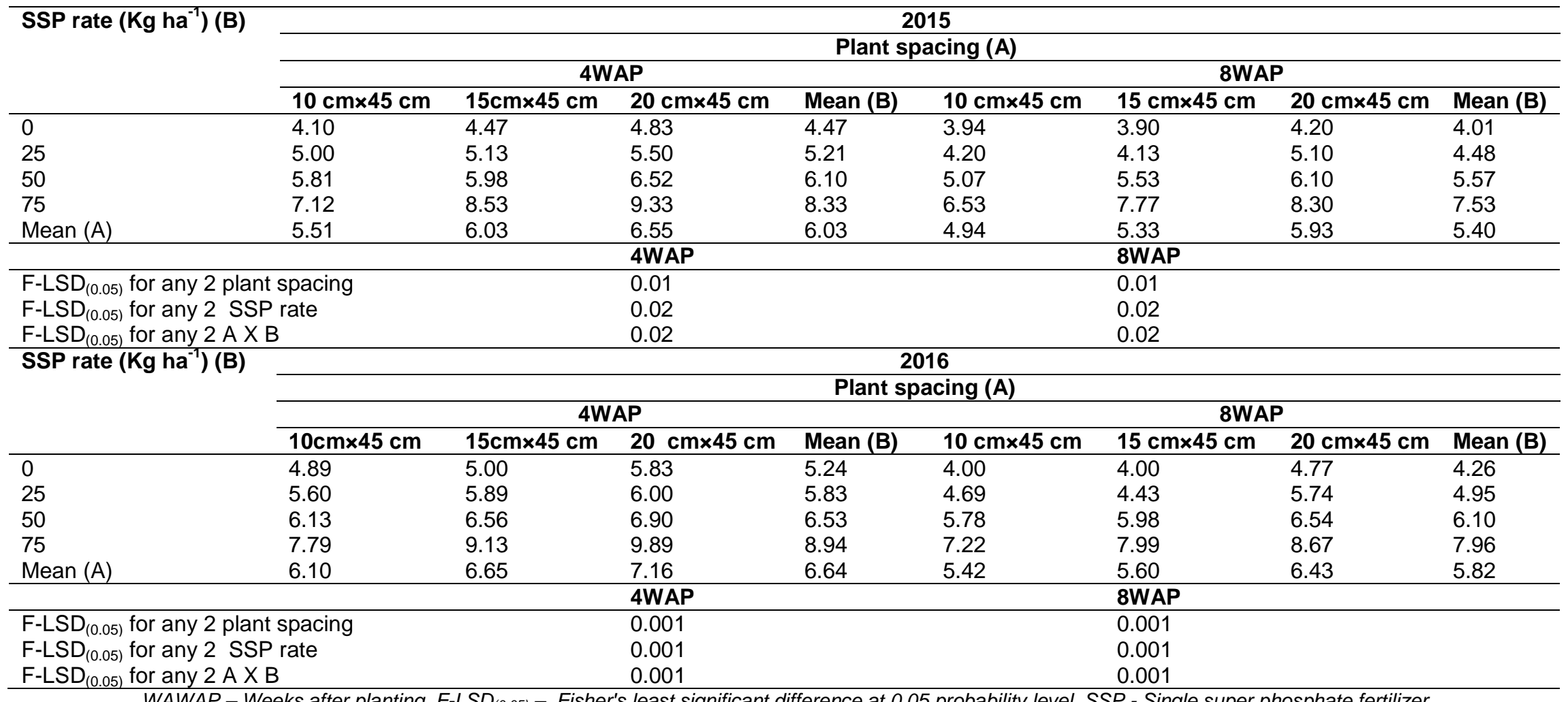


Table 10. Effect of single super phosphate fertilizer rate and plant spacing on potassium $\left(\mathrm{c} \mathrm{mol} \mathrm{kg}^{-1}\right)$ content of soil at four and eight weeks after planting

\begin{tabular}{|c|c|c|c|c|c|c|c|c|}
\hline \multirow[t]{4}{*}{ SSP rate $\left(\mathrm{Kg} \mathrm{ha}^{-1}\right)(\mathrm{B})$} & \multicolumn{8}{|c|}{2015} \\
\hline & \multicolumn{8}{|c|}{ Plant spacing (A) } \\
\hline & \multicolumn{4}{|c|}{ 4WAP } & \multicolumn{4}{|c|}{ 8WAP } \\
\hline & $10 \mathrm{~cm} \times 45 \mathrm{~cm}$ & $15 \mathrm{~cm} \times 45 \mathrm{~cm}$ & $20 \mathrm{~cm} \times 45 \mathrm{~cm}$ & Mean (B) & $10 \mathrm{~cm} \times 45 \mathrm{~cm}$ & $15 \mathrm{~cm} \times 45 \mathrm{~cm}$ & $20 \mathrm{~cm} \times 45 \mathrm{~cm}$ & Mean (B) \\
\hline 0 & 0.03 & 0.04 & 0.05 & 0.04 & 0.02 & 0.03 & 0.04 & 0.03 \\
\hline 25 & 0.06 & 0.07 & 0.07 & 0.07 & 0.05 & 0.06 & 0.06 & 0.06 \\
\hline 50 & 0.08 & 0.08 & 0.08 & 0.08 & 0.07 & 0.07 & 0.07 & 0.07 \\
\hline 75 & 0.09 & 0.09 & 0.09 & 0.09 & 0.08 & 0.08 & 0.08 & 0.08 \\
\hline \multirow[t]{2}{*}{$\operatorname{Mean}(\mathrm{A})$} & 0.07 & 0.07 & 0.07 & 0.07 & 0.06 & 0.06 & 0.06 & 0.06 \\
\hline & & & 4WAP & & & 8WAP & & \\
\hline \multirow{3}{*}{\multicolumn{2}{|c|}{ 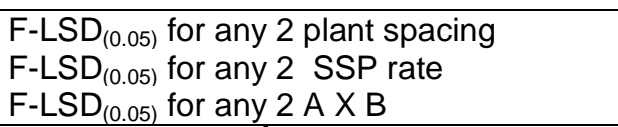 }} & & 0.001 & & & 0.001 & & \\
\hline & & & 0.001 & & & 0.001 & & \\
\hline & & & 0.001 & & & 0.001 & & \\
\hline \multirow[t]{4}{*}{ SSP rate $\left(\mathrm{Kg} \mathrm{ha}^{-1}\right)(\mathrm{B})$} & \multicolumn{8}{|c|}{2016} \\
\hline & \multicolumn{8}{|c|}{ Plant spacing (A) } \\
\hline & \multicolumn{4}{|c|}{ 4WAP } & \multicolumn{4}{|c|}{ 8WAP } \\
\hline & $10 \mathrm{~cm} \times 45 \mathrm{~cm}$ & $15 \mathrm{~cm} \times 45 \mathrm{~cm}$ & $20 \mathrm{~cm} \times 45 \mathrm{~cm}$ & Mean (B) & $10 \mathrm{~cm} \times 45 \mathrm{~cm}$ & $15 \mathrm{~cm} \times 45 \mathrm{~cm}$ & $20 \mathrm{~cm} \times 45 \mathrm{~cm}$ & Mean (B) \\
\hline 0 & 0.04 & 0.04 & 0.06 & 0.05 & 0.03 & 0.04 & 0.05 & 0.04 \\
\hline 25 & 0.07 & 0.06 & 0.07 & 0.07 & 0.05 & 0.06 & 0.07 & 0.06 \\
\hline 50 & 0.08 & 0.09 & 0.08 & 0.08 & 0.06 & 0.07 & 0.07 & 0.07 \\
\hline 75 & 0.09 & 0.09 & 0.09 & 0.09 & 0.07 & 0.08 & 0.08 & 0.08 \\
\hline \multirow[t]{2}{*}{ Mean $(\mathrm{A})$} & 0.07 & 0.07 & 0.08 & 0.07 & 0.05 & 0.06 & 0.07 & 0.06 \\
\hline & & & 4WAP & & & 8WAP & & \\
\hline \multirow{3}{*}{\multicolumn{2}{|c|}{$\begin{array}{l}\text { F-LSD }_{(0.05)} \text { for any } 2 \text { plant spacing } \\
\text { F-LSD }_{(0.05)} \text { for any } 2 \text { SSP rate } \\
\text { F-LSD }_{(0.05)} \text { for any } 2 \mathrm{~A} \times \mathrm{B}\end{array}$}} & & 0.001 & & & 0.001 & & \\
\hline & & & 0.001 & & & 0.001 & & \\
\hline & & 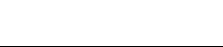 & 0.001 & & & 0.001 & & \\
\hline
\end{tabular}


The results presented in Table 7 reveal that the main effects of plant spacing, SSP rates and the interaction effects of plant spacing and SSP rates were significant $(P=.05)$. Plots which had the lowest population density (111,111plants hectare $\left.^{-1}\right)$ and received the highest rate of SSP $\left(75 \mathrm{~kg} \mathrm{P} \mathrm{ha}^{-1}\right)$ gave significantly $(P=.05)$ the highest number of fresh pods per plant at harvest (17.67 in 2015 and 19.00 in 2016) and weight of fresh pods per plant $\left(248.03 \mathrm{~g} \mathrm{plant}^{-1}\right.$ in 2015 and $290.76 \mathrm{~g} \mathrm{plant}^{-1}$ in 2016 respectively) than the other treatments. Hence, optimum spacing induces the plant to achieve its potential yield [15] and [16], indicated that cowpea plants produced at the lowest densities produced more number of pods than those at the higher densities.

Total nitrogen concentration of soil showed in Table 8 were significantly $(P=.05)$ higher in plots which received $75 \mathrm{~kg} \mathrm{P}^{-1}$ SSP $(0.06 \%$ at $4 \mathrm{WAP}, 0.05 \%$ at $8 \mathrm{WAP}$ in 2015 and $0.06 \%$ at $4 \mathrm{WAP}$ and $0.04 \%$ at 8 WAP in 2016 respectively) than the other treatments. From the results, the levels of total nitrogen in soil were higher at 4WAP than at 8WAP. This is attributed to the increase in the number of nodules and this nodules harbors bacteria that fix nitrogen to the soil. The highest amounts of phosphorus present in soil were observed in plots $(9.33 \mathrm{c} \mathrm{mol}$ $\mathrm{kg}^{-1}$ at 4WAP, $8.30 \mathrm{c} \mathrm{mol} \mathrm{kg}^{-1}$ at 8 WAP in 2015 and $9.89 \mathrm{c} \mathrm{mol} \mathrm{kg}^{-1}$ at $4 \mathrm{WAP}$ and $8.67 \mathrm{c} \mathrm{mol} \mathrm{kg}^{-1}$ at 8WAP in 2016) which had the lowest plant population density and fertilized with $75 \mathrm{~kg} \mathrm{P}^{\mathrm{P}}{ }^{-1}$ of SSP (Table 9). Potassium concentration of soil showed in Table 10 were significantly $(P=.05)$ higher in plots which received $75 \mathrm{~kg} \mathrm{P}^{-1} \mathrm{SSP}$ $\left(0.09 \mathrm{c} \mathrm{mol} \mathrm{kg}^{-1}\right.$ at $4 \mathrm{WAP}, 0.08 \mathrm{c} \mathrm{mol} \mathrm{kg}^{-1}$ at $8 \mathrm{WAP}$ in 2015 and $0.09 \mathrm{c} \mathrm{mol} \mathrm{kg}^{-1}$ at $4 \mathrm{WAP}$ and $0.08 \mathrm{c} \mathrm{mol} \mathrm{kg}^{-1}$ at 8WAP in 2016 respectively) than the other treatments. This use of SSP as a fertilizer material accounted for the increase in the phosphorus and potassium level of the soil at an increasing application rate.

\section{CONCLUSION}

The results of this study revealed that there was a consistent significant increase $(P=.05)$ among the single super phosphate fertilizer rates $(0 \mathrm{~kg} P$ $\mathrm{ha}^{-1}, 25 \mathrm{~kg} \mathrm{P} \mathrm{ha}{ }^{-1}, 50 \mathrm{~kg} \mathrm{P} \mathrm{ha-1}$ and $75 \mathrm{~kg} \mathrm{P} \mathrm{ha}^{-1}$ ) on the plant height, leaf area index, number of nodules per plant, number of fresh pods per plant, weight of fresh pods per plant of Bambara groundnut and effects on soil nutrient statues grown in an utisol in south east Nigeria in 2015 and 2016 cropping season, respectively. For optimum agronomic performances of Bambara groundnut it is recommended that it should be cultivated on soil fertilized with $75 \mathrm{~kg} \mathrm{P}^{-1}$ of single super phosphate fertilizer and plant spaced at $20 \mathrm{~cm} \times 45 \mathrm{~cm}$.

\section{COMPETING INTERESTS}

Authors have declared that no competing interests exist.

\section{REFERENCES}

1. Ocran VK. Seed management manual for Ghana. Accra Ghana: MOFA; 1998.

2. Mkandawire $\mathrm{CH}$. Review of bambara groundnut production in sub-Saharan Africa. Agricultural Journal. 2007;2:46470

3. Linnemann AR. Bambara groundnut (Vigna subterranea (L.) Verdc.): A review. Abstr. On Tropical Agriculture. 1987;12(7).

4. FAO. Legumes in human nutrition. FAO Food and Nutrition Paper No. 20. FAO, Rome; 1982.

5. Azam-Ali SN, Sesay A, Karikari SK, Massawe FJ, Aguilar-Manjarrez J, Bannayan M, Hampson KJ. Assesing the potential of an underutilized crop- A case study using bambara groundnut. Exp. Agric. 2001;37:433-472.

6. NRC. Lost crops of Africa, Volume II: Vegetables. National research council, development, security, and cooperation policy and global affairs, Washington. New York, Academic Press. 2006;354.

7. Yamaguchi M. World Vegetables. New York: Van Nostrand Reinhold; 1983.

8. Dansi AR, Vodouhe P, Azokpota, et al. diversity of the neglected and underutilized crop species of importance in Benin. The Scientific World Journal. 2012;932947.

9. Anikwe MAN. Soil quality assessment and monitoring: A review of current research efforts. New Generation Ventures Ltd., Enugu southeast Nigeria; 2006.

10. Khan MS, Zaidi A, Munees Ahemad, Oves $\mathrm{M}$, Wani PA. Plant growth promotion by phosphate solubilizing fungi - current perspective. Archives of Agronomy and Soil Science. 2010;56(1):73-98.

11. Kleinman PJA, Bryant RB, Rad WS. Development of pedotranfer functions to quantity phosphorus saturtion of 
agricultural soil. Journal of Environmental Quality. 1999;28:2026-2030.

12. Pandy P, Masheshwari DK. Two-species microbial consortium for growth promotion of Cajanus cajan. Curr Sci. 2007;92;11371141.

13. Agba OA, Ikenganyia EE, Asiegbu JE. Responses of Mucuna flagellipes to Phosphorus Fertilizer Rates in an Ultisol. International Journal of Plant \& Soil Science. 2016;9(2):1-9.

14. Ahmed MEN, Abdelrhim AJ. Effect of plant density and cultivar on growth and yield of cowpea (Vigna unguiculata L. Walp). Aust. J. Basic Appl. Sci. 2010;4(8):3148-3153.

15. Hamad MS. Effect of planting density on the performance of three cultivars of cowpea. M.Sc. Thesis, University of Khartoum, Sudan; 2004.

16. Asiwe JAN, Kutu RF. Interactive effect of row spacing on weed infestation and yields of four cowpea varieties. Afr. Crop Sci. Conf. Proc. 2009;9:293- 297.

17. Anikwe MAN, Ikenganyia EE, Egbonimale J, Oputah C. Assessment of some tropical plants for use in the phytoremediation of petroleum contaminated soil: Effects of remediation on soil physical and chemical properties. International Journal of Plant \& Soil Science. 2017;14(2):1-9.

18. Anikwe MAN, Agu JC, Ikenganyia EE. Agronomic evaluation of four exotic tropicalvarieties of watermelon (Citrullus lanatus L.) in two agro-environments in Nigeria. International Journal of Plant \& Soil Science. 2016;10(2):1-10.

19. Page JR, Miller $\mathrm{RH}$, Keeney DR, Baker DE, Roscoe Ellis JR, Rhoades JD. Methods soil analysis 2. Chemical and microbiology properties ( $2^{\text {nd }}$ Edn.) Madison, Wisconsin, U.S.A. 1982;1159.

20. Bremner JM, Mulvaaney CS. Total nitrogen. In: Page, A.L. (Eds.). Methods of soil analysis, Part 2. Chemical and microbial properties, second edition agronomy series no. 9 Madison, WI, USA, ASA, SSSA; 1982.

21. Bray RH, Kurtz LT. Determination of total, organic and available forms of phosphorus in soils. Soil Science. 1945;91-96.

22. Murphy J, Riley JP. A modified single solution method for determination of phosphate in natural waters. Anal. Chem. Acta. 1962;27:31-36.
23. Anderson JM, Ingram JSI (Eds). Tropical soil biology and fertility: A handbook of methods ( $2^{\text {nd }}$ edition). CAB International. 1993;221.

24. McLean EO. Soil $\mathrm{pH}$ and lime requirements. In: Page, A.L. (Eds.). Methods of soil analysis, Part 2. chemical and microbial properties, second edition agronomy series no. 9 Madison, WI, USA, ASA, SSSA; 1982.

25. Rhoades JD. Cation exchange capacity. In; Page, AL, Miller RH, Keeney DR, (eds.). Methods of soil analysis, Part 2: chemical methods. Agronomy monograph no. 9, American Society of Agronomy Madison, Wisconsin, USA; 1982.

26. Chapman HD. Total Exchangeable bases. In. C.A. Black (ed.), methods of soil analysis, Part 2. ASA, Madison, USA. 1982;9:902-904.

27. Gee GW, Bauder D. Particle size analysis. In: Dane JH, Topp GC. (Eds). Methods of Soil Analysis. Part 4, Physical methods. Soil sci. soc. Am. 2002;5:255-293.

28. Blanco FF, Folegatti MV. A new method for estimating the leaf area index $f$ cucumber and tomato plants. Hortic. Bras. 2003;2(4): 666-669.

29. Radford PJ. Growth analysis formula: Their use and abuse. Crop Sci. 1986;7(3):171-175.

30. Brown RB. Growth of the plant. In physiological Basis of crop growth and development. Amer. Soce. Agron. 1984;8:153-173.

31. Gomez KA, Gomez AA. Statistical producers for agricultural research. 2nd Edition. John Wiley and Sons. Inc. New York, USA; 1984.

32. GENSTAT Release 7.2DE, Discovery Edition 3, Lawes Agricultural Trust, Rothamsted Experimental Station. GENSTAT; 2007.

33. Effa EB, Nwagwu FA, Osai EO, Shiyam JO. Growth and yield response of bambara groundnut (Vigna subterranea (L.) Verdc) to varying densities and phosphate fertilizer rates in Calabar, South Eastern Nigeria. Journal of Biology, Agriculture and Healthcare 2016;6(16).

34. Agbo AE, Gmakri D, Beugre GM, Fondio $L$, Kouame C. Effects of intercropping on maturity degree of four okra fruit varieties and their nutrient composition. Elect. J. Food Plant Chem. 2008;5:1-4. 
35. Muoneke CO, Asiegbu JE. Effect of okra planting density and spatial arrangement in intercrop with maize on the growth and yield of the component species. Journal of Agronomy and Crop Science 1997;179: 201-207.

(C) 2017 Ikenganyia et al.; This is an Open Access article distributed under the terms of the Creative Commons Attribution License (http://creativecommons.org/licenses/by/4.0), which permits unrestricted use, distribution, and reproduction in any medium, provided the original work is properly cited.

Peer-review history:

The peer review history for this paper can be accessed here: http://sciencedomain.org/review-history/20129 